\title{
Rhetorical Theatron in Late Byzantium: The Example of Palaiologan Imperial Orations
}

\author{
IDA TOTH
}

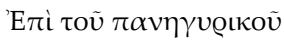

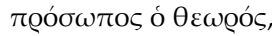

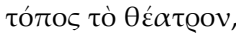

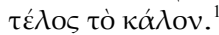

A Festschrift - celebration in writing - is undoubtedly an appropriate place to discuss the issue of celebratory oratory, all the more so when the honorand has dedicated a significant quantity of his own work to similar concerns. This is certainly the case with Professor Georgios Fatouros, whose academic output includes several major studies of rhetorical subjects. For that reason, the general theme of the present paper is rhetoric as one of the most developed and widely practiced literary phenomena of both classical times and the Middle Ages. Though just as broad and comprehensive, the character of this discipline in Byzantium was somewhat altered by the prevalence of epideictic, or celebratory oratory over the remaining rhetorical genres. This effect was generated by practical use, which rendered encomiastic performances ubiquitous, very often featuring as obligatory elements of state and church ceremonial, or simply flavouring the social scene of Byzantine academic elites.

It is precisely the ideas of the theatron and performance that connect the main topic of the present volume to the task of examining late Byzantine court rhetoric, an assignment entrusted to me by its editor. Such an investigation is amply justified in the light of classical and medieval rhetorical practices, as well as from the viewpoint of ancient, medieval and modern literary criticism.

It goes without saying that rhetoric represents a performative art, and that its major concerns are exactly delivery and the effect it has on its audience. Epideictic rhetoric in particular, as a predominant $\varepsilon \tilde{i} \delta$ o $\varsigma$ of practical oratory in "the highly ritualistic organization of the Byzantine polity as a "theatre state", displays a

1 "As regards panegyric, the person (scil. addressed) is the spectator; the setting is the theatron; the objective is the noble"; Anonymi in Hermogenem e codice Paris. 3032, in: H. Rabe, Prolegomenon sylloge, Leipzig 1935, 231.

2 P. Roilos, The Sacred and the Profane: re-enacting ritual in the medieval Greek novel, in: D. Yatromanolakis/P. Roilos (eds.), Greek Ritual Poetics, Cambridge, Mass./London 2004, 213. 
character that is visual as well as dramatic. Still, the emphasis on the similarities between rhetoric and drama is by no means restricted to the Middle Ages, nor is it exclusively Byzantine. The rhetorical aspect of drama and the dramatic character of rhetoric were considered significant enough in classical antiquity to invite shared terminology. Furthermore, interest in the joint issues of rhetoric and drama was renewed in the Renaissance, inevitably leading to a further and continuing fusion of rhetorical concepts and dramatic theory. ${ }^{3}$

The idea of the rhetorical theatron in Byzantium only confirms this connection. Defined as "an encounter between a rhetorical performer - either an established master of the art or a young school leaver making his début - and a critical audience" ${ }^{4}$, this cultural phenomenon is attested to as clearly in Byzantine sources as in modern scholarship. ${ }^{5}$ Yet it is still the case that some studies of Byzantine theatre have disregarded the theatrical setting of rhetoric. ${ }^{6}$ The same is true of dictionaries of later Greek, which define theatron either as a place for public assemblies, or as a spectacle, of any description, seen in such a venue. ${ }^{7}$ Without exception, these definitions fail to register that this term was used from late antiquity through to late Byzantium to denote circles of intellectuals, who gathered to present their own literary work, and to listen in turn to the work of other authors being performed. This usage seems to have been particularly popular in the Palaiologan period, with several outstanding scholars, such as Nikephoros

3 R. G. A. Buxton, Persuasion in Greek Tragedy, Cambridge 1982; M. Heath, The Poetics of Greek Tragedy, London 1987; J. Ober/B. Strauss, Drama, political rhetoric and the discourse of Athenian democracy, in: J. J. Winkler/F. I. Zeitlin (eds.), Nothing to Do with Dionysos? Athenian Drama in Its Social Context, Princeton, N. J. 1990, 237-71; R. Scodel, Drama and Rhetoric, in: S. E. Porter (ed.), Handbook of Classical Rhetoric in the Hellenistic Period 330 BC-AD 400, Leiden/New York/Cologne 1997, 489-504. G. K. Hunter, Rhetoric and Renaissance Drama, in: P. Mack (ed.), Renaissance Rhetoric, London 1994, 103-18.

4 P. Magdalino, The Empire of Manuel I Komnenos, 1143-1180, Cambridge 1993, 339.

5 H. Hunger, Die hochsprachliche profane Literatur der Byzantiner (HdAW 12/1-2, Byzantinisches Handbuch V 1-2), Munich 1978, I, 210-11; Magdalino, The Empire of Manuel (see n. 4), 336-56; M. Mullett, Aristocracy and patronage in the literary circles of Comnenian Constantinople, in: M. Angold (ed.), The Byzantine Aristocracy IX to XIII Centuries (BAR, International Series, 221), Oxford 1984, 173-202; S. Mergiali, L'Enseignement et les lettrés pendant

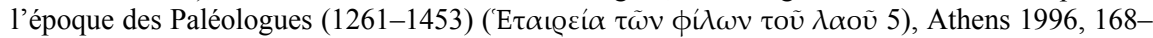
70. The forthcoming publication of the proceedings of the Spring Symposium of Byzantine Studies, held in Belfast in 2005, and dedicated to the issue of performance in Byzantium, is bound to further our understanding of this issue.

6 Puchner's survey is a case in point: W. Puchner, Zum 'Theater' in Byzanz. Eine Zwischenbilanz, in: G. Prinzing/D. Simon (eds.), Fest und Alltag in Byzanz, Munich 1990, 11-16.

7 S.v. $\theta \varepsilon ́ \alpha \tau$ toov: F. W. Danker, A Greek-English Lexicon of the New Testament and Other Early

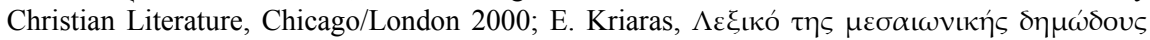

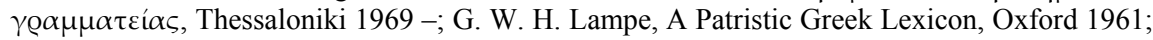
E. A. Sophocles, Greek Lexicon of the Roman and Byzantine Periods (146 BC-1100 AD), Cambridge, Mass./London 1914; LBG. 
Gregoras, Demetrios Kydones, Manuel II Palaiologos and John Chortasmenos, showing a particular penchant for it in their writing. A simple text search in the TLG database provides abundant evidence for the frequency of the term's employment at the time. For this reason, the focus of the present paper will not be on the instances of textual referencing to the word theatron, but on the testimonies of performance that such material offers. Texts studied here belong to one distinct type of celebratory oratory - Palaiologan imperial orations - while a specific concern in their assessment regards the presentation of the orations, as it featured in the physical and fictional space of the late Byzantine rhetorical theatron.

\section{The Pragmatics of Late Byzantine Imperial Orations}

Imperial orations are rhetorical compositions in prose, which praise emperors and their achievements. The late Byzantine imperial orations known to us today constitute a substantial portion of the whole body of extant Byzantine speeches dedi-

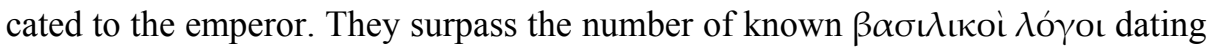
from the period between the fourth and sixth centuries, and equal the amount of similar texts dated to the eleventh and twelfth centuries. As to their original quantity, it is impossible to give a precise figure. Surviving orations and references to lost texts in written sources, estimated at circa forty, allow us to give a rough quote of more than twenty aspiring authors who honoured every Byzantine emperor in the period $1261-1453 .^{8}$

Imperial orations by and large represented literary and political phenomena with a specific role in both the rhetorical production and the public life of Byzantium. Throughout their history, these pieces of occasional oratory maintained their

8 On late Byzantine imperial orations, see: D. G. Angelov, Imperial Ideology and Political Thought in Byzantium, 1204-1330, Cambridge 2007; idem, Byzantine Imperial Panegyric as Advice Literature, 1204-ca. 1350, in: E. Jeffreys (ed.), Rhetoric in Byzantium. Papers from the Thirty-fifth Spring Symposium, Exeter-College, University of Oxford, March 2001, Aldershot 2003, 55-72; R. Gouilland, Essai sur Nicéphore Grégoras, Paris 1926, 147-56; N. Radošević, Похвална слова цару Андронику II Палеологу (The Encomia to the Emperor Andronikos II Palaiologos), in: ZRVI 21 (1982) 61-83; eadem, Иноплеменици у царскии говорима епохе Палеолога, in: ZRVI 22 (1983) 119-43; I. Toth, Imperial Orations in Late Byzantium, unpublished doctoral thesis, Oxford 2003. Studies of secondary literature on this topic mostly accompany the editions of the orations, and concern individual orations, not the genre as a whole. Lists of late Byzantine imperial orations can be found in: Hunger, Hochsprachliche profane Literatur (see n. 5), I 129-32, 145-57; Radošević, Иноплеменици, 143. Neither is complete, mainly because of the existing inconsistencies in the understanding of the term imperial oration. For example, although Hunger stresses the difficulty of defining separate genres in encomiastic rhetoric (Hunger, Hochsprachliche profane Literatur [see n. 5], I 145), he differentiates between imperial encomia and occasional speeches for emperors, thus occasionally separating rhetorical compositions that may be viewed as being of the same type. 
twofold character: while their form and content remained strongly attached to the long-lasting ancient encomiastic tradition, Byzantine imperial orations were never lacking in innovative and contemporary elements. This unlikely and often ambiguous synthesis had, nevertheless, a precisely defined function in the immediate circumstances of performance. Still, it is exactly the consideration of the public and social aspects of the imperial oration that represents the first stumbling block in the investigation of the pragmatics of this rhetorical type. Rhetorical theory concerned with the $\beta \alpha \sigma \iota \lambda \iota \kappa o ̀ ~ \lambda o ́ \gamma o \varsigma$ does not serve as a manual for presentation, gestures, vocal modulations or costume prescribed for its performance. Furthermore, owing to our lack of knowledge of the experience shared by the orator and the audience, we cannot claim any understanding of the effects that the performer

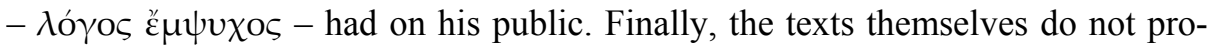
vide much detail on these matters either. Owing to their deliberate obscurity, the information that we have is, in addition to being sparse, also predominantly unspecific, and only rarely supported or supplemented by other written testimonies. It is therefore one of the aims of this paper to suggest possible ways of bridging the gap between the significant amount of available rhetorical material and the lack of evidence regarding its original use and function.

In the first instance, an assessment of the genre of imperial orations will be attempted in order to identify how their authors/performers and audience understood these pieces. In the second, specific data on performance in primary sources, however meagre they are, will be consulted and gauged. Furthermore, this paper employs a range of approaches known as pragmatics, as they are found in performance criticism, in order to compensate for the loss of public and social aspects of imperial orations by examining internal evidence for the contextualization of these texts. ${ }^{9}$ More precisely, it focuses on the performers' description of themselves and of the public occasions and ceremonial, which instigated their contributions in the first place. The encomia under consideration are very often

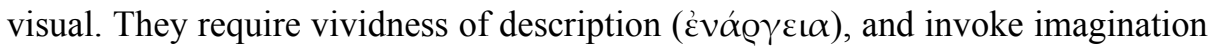
and visualisation $(\phi \alpha \nu \tau \alpha \sigma i \alpha)$, on the part of the spectator and reader alike. If we take this into consideration, it becomes possible to remove the pragmatics of the orations from the immediate context of their delivery, and to perpetuate their performative qualities through the act of reading, and beyond the constraints of the original setting.

9 The seminal study of J. L. Austin, How to do things with words, Cambridge, Mass. 1962, still provides the most effective introduction to performance criticism. R. Schechner, in: Performance Studies. An introduction, London/New York 2002, gives a valuable preview of the range and utility of performance studies. When considering the issues of text and context, J. Derrida's discussion of theories of speech and writing, and in particular his essay "Plato's Pharmacy", in: Dissemination (Continuum), London/New York 2004, 69-186 are thought-provoking. 
Any research on Byzantine rhetoric has to be carried out with respect to the rhetorical situation - $\kappa \alpha$ íoos - and with regard to implied meanings and perspectives. It is my contention that an equal consideration of the matters of the setting, occasion, performer and audience delivers results that fully validate the combined approach.

\section{The Genre}

In order to understand the performative aspect of imperial orations, it is important to address the issue of the genre of these rhetorical compositions. Indeed, many pragmatics-based approaches acknowledge that this question plays a highly significant role in our understanding of the context of literary texts in general. ${ }^{10} \mathrm{In}$ doing so, they place emphasis on the social and intellectual ground shared by the author and his audience, which creates a communicative exchange between them. In other words, a consideration of genre may elucidate how literary works were composed, how they were received in their original setting, and, in consequence, how they provided mutual understanding between the performers and their public.

This being so, the current investigation of the workings of late Byzantine imperial orations turns to explore the concept of the genre of these compositions as it was understood in contemporary Byzantium. ${ }^{11}$ To begin with, it highlights the question of the relevance of the traditionally accepted definition of the imperial oration as an encomium to the late Byzantine rhetorical practice. ${ }^{12}$

In late Byzantium, as earlier, the principal handbook on the composition of the imperial oration was the second treatise attributed to Menander Rhetor. Most manuscripts of this work extant today have come down to us from the late Byzantine period, and its popularity in this epoch must not be ignored, even if, as far as is known, no Byzantine scholar felt drawn to discuss or comment upon Menander in the way that they did on Aphthonios and Hermogenes. ${ }^{13}$ However, quite apart from the number of surviving manuscripts, the likely influence of Menander's prescriptions can also be detected in the fact that other theoreticians of rhetoric in

10 For brief and informative previews of such approaches, see: G. W. Most, Generating genres: the idea of the tragic, in: M. Depew/D. Obbink (eds.), Matrices of Genre: authors, canons and society, Cambridge, Mass./London 2000, 1-22 and J. W. Day, Epigram and reader: generic force as (re-)activation of ritual, in: ibidem, 38-42.

11 I discussed this topic in detail in my paper given at the 21st International Congress of Byzantine Studies in London (2006), and am currently working towards its publication.

12 Here I refer to the definition of the imperial oration attributed to the third-century author

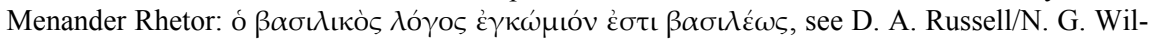
son, Menander Rhetor, Oxford 1981, 76.

13 On the textual transmission of this treatise, see: Russell/Wilson, Menander Rhetor (see n. 12), xl-xliv. 
late Byzantium reproduced entire passages of his manual. For example, in the first quarter of the fourteenth century, the monk Joseph, known both as the Philosopher, and as Rhakendytes, included Menander's entire chapter on the basilikos logos in his own synopsis of rhetoric. In a chapter entitled $\pi \varepsilon$ ¿i tov $\pi \alpha v \eta$ -

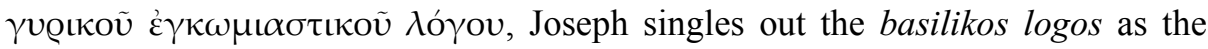
most distinctive example of the panegyrical eĩoos, and gives precepts for its composition. ${ }^{14}$ Since this scholar was renowned for his knowledge of rhetoric, and was well connected in the highest intellectual circles, we can assume that his handbook exerted influence on a number of contemporary imperial encomiasts. The contribution of Joseph's compendium to Menander's treatise on the basilikos logos, on the other hand, is less substantial. Apart from indicating that the imperial oration occupied a significant role in late Byzantine oratory, nothing that Rhakendytes says adds to Menander, nor does it make us any more familiar with the concrete customs of praising the emperor in fourteenth-century Byzantium.

The first Palaiologan imperial encomiast who discusses the type of his oration and the structure of his composition is Manuel/Maximos Holobolos in the midthirteenth century. ${ }^{15}$ From the outset we are in no doubt as to how Holobolos defines his work: it is an encomium. According to this orator, anybody who is dedicated to composing encomia firstly examines the origin, then the birth, divine signs, upbringing, accomplishments, followed by the actions, and everything else that has been granted to the honorand by nature, education or divine providence. After these headings, the encomiast should proceed to praise the physical qualities of his laudandus, and finally his internal, intellectual qualities. According to Holobolos, the latter area of praise should be executed with respect to the four cardi-

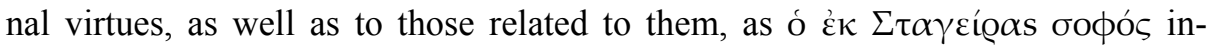
structed, and others who devoted themselves to the study of the philosophical subject of ethics. It is clear that in his definition of encomium Holobolos keeps to the basic tripartite scheme - externals, body, mind - which can be traced back to Aristotle. ${ }^{16}$ Holobolos himself explicitly refers to Aristotle and his followers as the model for his writing. In doing so, he may have been more intent on displaying his own familiarity with Aristotelian philosophy than on revealing the theoretical background of his rhetorical composition. Although his actual models can be found in the rhetorical prescriptions for the composition of encomia included

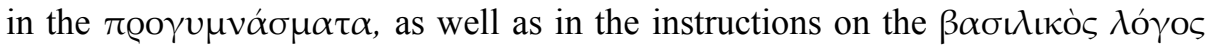
by Menander, Holobolos opted against revealing these sources.

14 The synopsis was included in Rhakendytes's encyclopaedic work, ed. C. Walz, Rhetores Graeci, Tübingen 1834, III 547-58.

15 Holobolos, Encomium I, in: M. Treu, Manuelis Holoboli orationes, in: Programm des königlichen Victoria-Gymnasiums in Potsdam (1906) 32, 16-34.

16 Aristotle, Nicomachean Ethics, $1098^{\mathrm{b}}$. 
The late Byzantine panegyrical practice promoted by Holobolos continued to flourish thereafter. Following the imperial orations for Michael VIII Palaiologos, a long series of encomia was composed for his son and successor, Andronikos II. Although the authors of these orations were highly accomplished rhetoricians with a profound knowledge of rhetoric, none of them discusses in much detail the genre to which his work belongs. Still, it is clear that they follow, and often even specifically refer to the tripartite scheme. ${ }^{17}$ They also define their compositions.

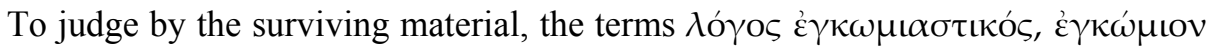

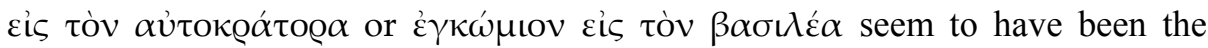
most popular designations of fully developed imperial orations in late Byzantium.

For another specific reference to the definition of an imperial oration we have

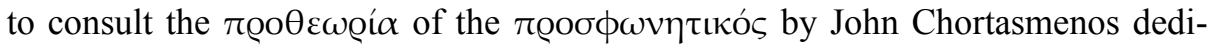
cated to the Emperor Manuel II Palaiologos at the beginning of the fifteenth century. ${ }^{18}$ Chortasmenos's description of his oration as panegyrical is based on the

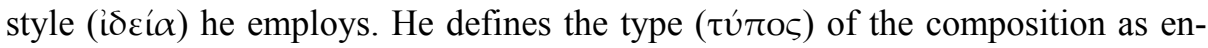

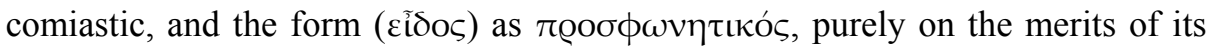
length. Chortasmenos goes on to number the concrete types of style, which appear in his oration, each of which is given a separate heading in Hermogenes, to whom he himself refers as his source. The $\pi$ @o $\theta \varepsilon \omega$ Qí $\alpha$ ends with the author's wish that his work may be judged solely on the grounds of its rhetorical value. To this we

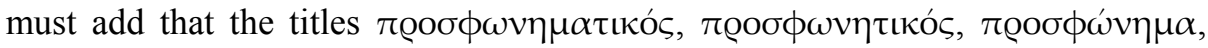

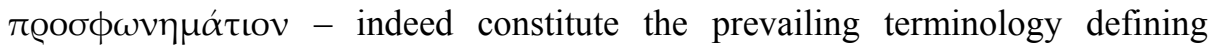
Palaiologan imperial orations, whose most obvious common denominator is their brevity.

This evidence shows that there are certain discrepancies between the terminology used to refer to late Byzantine imperial orations and Menander's usages.

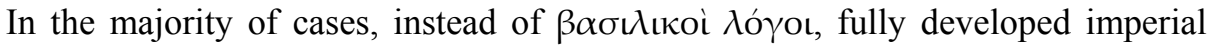
orations are defined as encomia or encomiastic orations. However, given the Menandrian definition of the imperial oration as an encomium, this only confirms that Palaiologan rhetoricians were by no means doubtful about the true nature of their task, regardless of how flexible they appear to have been accommodating the

17 Following rhetoricians refer to the same scheme: George of Cyprus (Encomium for Michael VIII, 324, ed.: J. F. Boissonade, Anecdota Graeca, Paris 1829 (Reprint 1962), I 313-58; Encomium for Andronikos II, 369, 370, ed., ibidem, 359-93), Nikephoros Choumnos (Encomium for Andronikos II, 14, ed: Boissonade, Anecdota Graeca, Paris 1830 [Reprint 1962], II 1-56), Maximos Planoudes (Basilikos, cc. 4, 5, ed.: L. G. Westerink, Le basilikos de Maxime Planude, in: BS1 27 [1966] 98-103; 28 [1967] 54-56; 29 [1968] 34-50) and Nicholaos Lampenos (Ora-

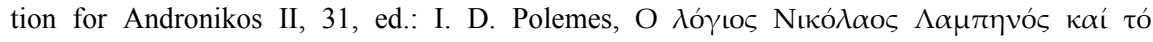

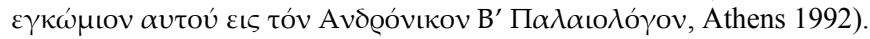

18 Ed.: H. Hunger, Johannes Chortasmenos, Briefe, Gedichte und kleine Schriften (WBS VII), Vienna 1969, 225-6. 
constraints of rhetoric. Moreover, addresses constitute the only other distinctly separate category of imperial orations in late Byzantium. These are shorter compositions, and represent only partial encomia. Thus, it is clear that in late Byzantium we can no longer detect a division of the encomiastic form of imperial orations into different types connected to the occasion when a particular oration was performed. Although we know that these compositions continued to be written for, and delivered at, various public events, such as the great church feasts, coronations, arrivals of the emperor, etc., their contents and composition do not seem to have depended much on those events. Here, once again, we encounter difficulties when taking Menander as a guide: while in connection with some other periods the range of his encomiastic types seems limited, in late Byzantium he looses contemporary relevance on account of being too extensive.

\section{The Occasion}

Imperial orations were composed with a view to their performance. This would take place when they were presented at social events, presided over by the emperor. Regrettably, their exact place within public life and the official ceremonial of the Byzantine court is not explicitly stated in any of existing narrative sources, and remains unknown. When considering this particular issue, we have to bear in mind that such testimonies, even if they were readily available, would have to be critically assessed: the Byzantine court ceremonial displayed variations and flexibility to suit particular occasions, and was subject to continuous change over the centuries. ${ }^{19}$ Furthermore, in late Byzantium, this change may well have been imposed by historical circumstances to which the repetition of long-established rituals ceased to be immediately relevant. It is therefore fortunate that we are able to ascertain that silence in the extant treatises on imperial ceremonies and the in records of their organization does not reflect actual practice. In fact, the authors of the imperial orations themselves reveal that the reverse is true. The obvious pride that they took in their compositions, and in their successful presentation, yields valuable facts. The titles, headings, colophons and prooemia of the imperial orations, or even occasional references in the correspondence of individual rhetoricians, volunteer some information on the circumstances of the composition and performance of their speeches.

19 On the Byzantine court ceremonial: A. Cameron, The construction of court ritual: the Byzantine Book of Ceremonies, in: D. Cannadine/S. Price (eds.), Rituals of Royality: power and ceremonial in traditional societies, Cambridge 1987, 106-36; M. McCormick, Analyzing Imperial Ceremonies, in: JÖB 35 (1985) 1-20. Both studies emphasize the changing nature of the court ceremonial in Byzantium. 
From such evidence we know that major ceremonies in late Byzantium, for which imperial orations were written, continued to coincide with great liturgical feasts. For example, it is very likely that at least one encomium by Manuel/ Maximos Holobolos was delivered on Christmas day. ${ }^{20}$ Manuel Gabalas/Matthew of Ephesos addressed the emperor on the occasion of the Feast of Assumption. ${ }^{21}$ Moreover, imperial victories in the battlefield, however rare they became in the Palaiologan period, still inspired the composition of imperial orations. George Akropolites, ${ }^{22}$ Demetrios Kydones, ${ }^{23}$ and Helena Kantakouzene Palaiologina ${ }^{24}$ are known to have composed imperial orations to commemorate imperial victories in the battlefield. Coronations, as the most solemn events in Byzantine public life, also gave rise to the delivery of encomia for emperors: Manuel/Maximos Planoudes, ${ }^{25}$ the Patriarch John XIV Kalekas, ${ }^{26}$ and Nicholas Kabasilas ${ }^{27}$ all wrote such orations, to commemorate the accession to the throne of Michael IX, John V and Matthew Kantakouzenos respectively.

In addition, some imperial encomia seem to have commemorated a number of special occasions, as, for example, the emperor's recovery from an illness, or his

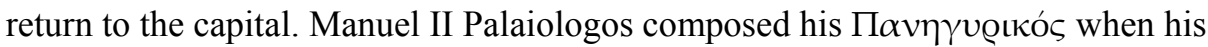

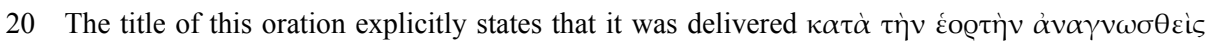
$\tau \tilde{\eta} \varsigma$ X loboli orationes, in: Programm des königlichen Victoria-Gymnasiums in Potsdam (1907) 51-77.

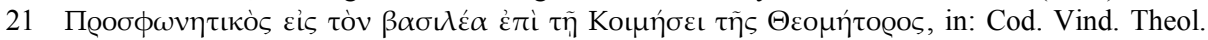
Gr. $174,271 \mathrm{v}-277 \mathrm{v}$.

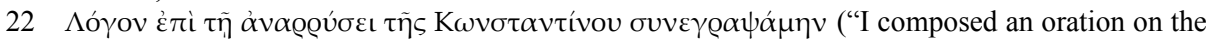
occasion of the recapturing of Constantinople"): A. Heisenberg, Georgii Acropolitae Opera, I, Leipzig 1903 (reprinted with additions and corrections by P. Wirth, Stuttgart 1978), 188, ch. 89. $20-1$.

23 The second imperial oration by Kydones for John VI Kantakouzenos was composed in February 1347 , immediately after the dramatic events that ended the six-year long civil war with a peace settlement. Throughout his oration, Kydones celebrates the victory of John VI, and refers to his triumphal entry to Constantinople: Demetrios Kydones, Oration II for John VI Kantakouzenos = G. Cammelli, Demetrii Cydonii orationes tres, adhuc ineditae, in: BNJ 4 (1923) 77-83.

24 In one of his letters to Helena Kantakouzene, Demetrios Kydones identifies this Byzantine empress as the author of oration(s) ( $\lambda$ ó $\gamma \mathrm{ol}$ ) dedicated to her father, the Emperor John VI Kantakouzenos. Kydones refers to Helena's compositions as غ̇ $\pi ı v i ́ k ı$ celebrating her father's victory of 1347: R.-J. Loenertz, Démétrius Cydonès Correspondance (StT 208), Vatican 1960, II no 389, 340-1; F. Tinnefeld, Demetrios Kydones, Briefe (Bibliothek der griechischen Literatur 12), Stuttgart 1981, I 1, 187-9.

25 Maximos Planoudes states that his oration was composed on the occasion of Michael IX's coronation: Planoudes, Basilikos (see n. 17), ch. 1, 25-7.

26 John XIV Kalekas, Coronation Speech $=$ P. Joannou, Joannes XIV Kalekas, Patriarch von Konstantinopel, unedierte Rede zur Krönung Joannes V, in: OCP 27 (1961) 43-5.

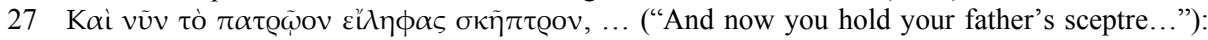
Nicholas Kabasilas, Encomium for Matthew Kantakouzenos = M. Jugie, Nikolas Cabasilas, Panégyriques inédits de Mathieu Cantacuzene et d'Anne Paléologine, in: IRAIK 15 (1911) 117, 6. 
father, John V, had recovered from a serious illness, ${ }^{28}$ while Manuel Gabalas/Matthew of Ephesos celebrated his own recovery with a speech for Andronikos II. ${ }^{29}$ In turn, John Chortasmenos addressed Manuel II when this ruler returned from Thessalonica to Constantinople in $1416 .{ }^{30}$

We know that several such texts were commissioned, and that their authors appear to have been formally invited to compose, and deliver, their orations. Cases of officially appointed orators, however, whose ceremonial duty was to produce imperial orations, were rare. In fact, only one such case can be identified:

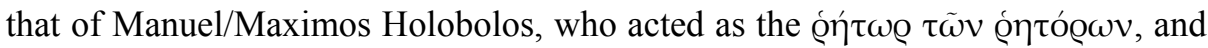
among whose responsibilities was included an annual celebratory speech for the emperor. ${ }^{31}$ Several further orators appear to have been officially invited to write imperial orations for specific public occasions: George Akropolites, Maximos Planoudes, and possibly also Gregory of Cyprus, John Kalekas, Nikolaos Kabasilas and Demetrios Kydones. Many encomiasts, however, were not so privileged, but were compelled to take a more active approach in seeking opportunities to address the emperor. If their unsolicited pursuits met with success, these eager hopefuls were granted audiences, and opportunities to present their work in less formal situations. The evidence we find in the correspondence of one such claimant to the status of imperial encomiast, Michael Gabras, is a case in point.

This Byzantine author belonged to a group of fourteenth-century intellectuals, who dwelt on the periphery of academic life, pleading for help and financial support. With the only source of information about Gabras being his surviving correspondence, not much is known about him. ${ }^{32}$ Although not held in high esteem by

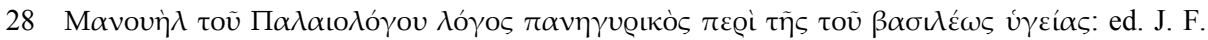
Boissonade, Anecdota nova, Paris 1844 (Reprint 1962), 223-38.

29 The address (

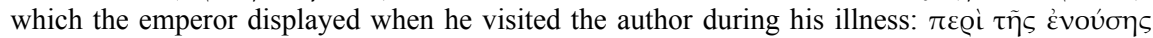

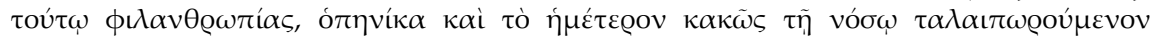

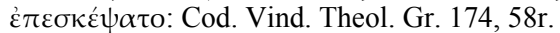

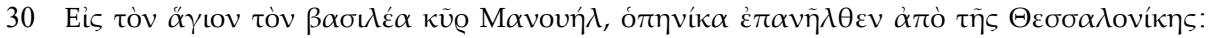
Hunger, Chortasmenos (see n. 18), 217-24.

31 R. Macrides, The New Constantine and the New Constantinople - 1261?, in: BMGS 6 (1980) $13-41$.

32 From Gabras's letters, we know that he was born into an old Byzantine family, that he may have been taught by the famous mathematician and astronomer Manuel Bryennios, and that he was attached to the imperial office in ca. 1320: A. Bryer, A Byzantine Family: The Gabrades c. 979c. 1653, in: Historical Journal 12/2 (1970) 164-87; A. Bryer/A. Dunn/J. Nesbitt, Theodore

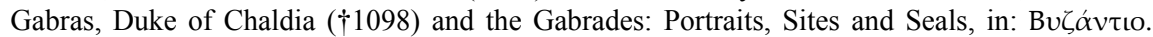

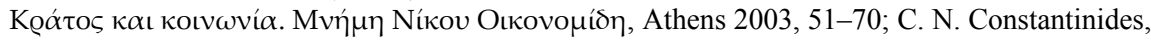
Higher Education in Byzantium in the thirteenth and early Fourteenth Centuries (1204-ca. 1310) (Texts and Studies of the History of Cyprus 11), Nicosia 1982, 96, and note 40; G. Fatouros, Die Briefe des Michael Gabras (ca 1290 - nach 1350) (WBS X 1-2), Vienna 1973, I 20 4; PLP 3372; Mergiali, Enseignement (see n. 5), 106-12. 
some modern scholars, ${ }^{33}$ Gabras's letters testify to many aspects of contemporary intellectual life. Undoubtedly their most striking characteristic is their petitioning nature: these missives clearly convey that the writer was in constant search of private or, indeed, imperial grants. More relevantly, they preserve evidence of Gabras's own literary output, mainly rhetorical, which has not survived to the present day. Thus, we know that he composed several imperial orations for Andronikos II, which he thereafter forwarded to his friends for evaluation. ${ }^{34} \mathrm{Al}$ though it seems that at least one such oration came into the emperor's hands and made a positive impression, public recitation of the work was not held, and the author's petition failed. ${ }^{35}$ These references represent a reminder that even those educated Byzantines who did not belong to imperial circles, and were not sufficiently privileged to present their works publicly, preferably before the emperor himself, wrote imperial orations and promoted them unendorsed. In fact, in time, and particularly during the last century of Byzantium, the dwindling of official demand meant that the imperial orations gradually lost their ceremonial component, and became increasingly private. However, this development did not end their production, which continued well into the fifteenth century, almost until the fall of Constantinople in 1453.

\section{The Setting}

With this array of different circumstances inspiring the composition of imperial orations, the next obvious question to ask is: what do we know about the actual performance of these texts in late Byzantium?

Firstly, where did they take place?

The great majority of imperial encomiasts established themselves in Constantinople, gravitating towards the imperial court. It is conspicuous, however, that many of them arrived from the territories that were no longer Byzantine. In fact, almost two thirds of the rhetoricians considered in this study were born in the Greek-speaking provinces of Europe and Asia Minor. The list of these authors is long. George Akropolites left Constantinople for Nicaea when this city became

33 Gabras's correspondence has been described as "bulky but pathologically empty of content": see I. Ševčenko, Theodore Metochites, the Chora and the intellectual trends of his time, in: P. A. Underwood (ed.), The Kariye Djami, London 1975, 20.

34 The editor of Gabras's correspondence has identified four imperial orations by this author, referred to in the following letters: 1) nos 49,52 ; 2) nos $281,284,286$; 3) no. 313; 4) no. 344. Cf. Fatouros, Briefe des Michael Gabras (see n. 32), I, 25.

35 The speech in question seems to be Gabras's second imperial oration composed in $c a$. 1322: Fatouros, Briefe des Michael Gabras (see n. 32), no 286. On the fate of this oration, see: ibidem, no. 281, 6-10 and 17-18; no. 284, 3-9. 
the seat of the Byzantine emperor. George/Gregory of Cyprus went from his native island to Nicaea, and later to Constantinople. Manuel/Maximos Planoudes moved from Nikomedeia in Bithynia to the Byzantine capital. Although indigenous to Constantinople, Theodore Metochites had to find his way back to the city of his birth, and to the imperial favour, after his family had been exiled to Asia Minor. Nicholaos Lampenos came to Constantinople from Thessalonica, as did Joseph the Philosopher, Nicholas Kabasilas and Demetrios Kydones. Theodore Hyrtakenos, Nikephoros Gregoras and John Dokeianos were natives of the coastal regions of the Sea of Marmara and the Black Sea. Manuel Gabalas/Matthew of Ephesos came from Philadelphia, while the families of Isidore of Kiev and Michael Apostoles originated from the Peloponnese.

Considering their honorand, it is very likely that the encomia, if and when presented to the emperor, were staged in the imperial palace. We should also allow for the possibility of the orations being read before an informal audience, in the houses of friends and correspondents, to whom these compositions may have been sent for evaluation and further recommendation. However, the orations themselves do not volunteer such information. Their authors do not seem to be particularly concerned with the actual performative context of their work. Instead, they are happy to communicate the descriptive context, which can unfailingly be identified as a stage much more imposing than any of the physical spaces in the Byzantine capital that we may be able to pinpoint.

Imperial orations are founded on the notion of society, and they imply a greater audience existing outside the confines of the theatre. This audience, as the orations themselves indicate, is ecumenical, and represents a compendium of the Byzantine populace as a whole. Possibly the most comprehensive illustration of such a magnificent theatron is found in Choumnos's encomium for Andronikos II. This orator depicts a gathering in celebration of the emperor comprising of:

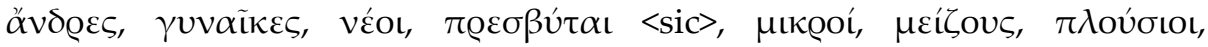

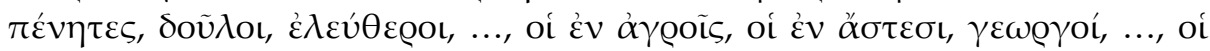

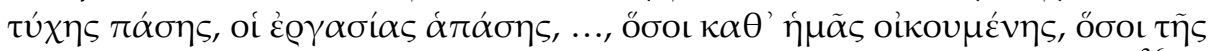

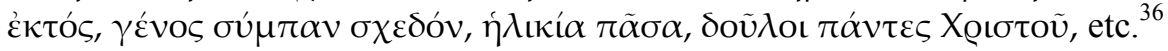

The rhetorical experience promoted by epideictic is designed to engage both the speaker and the listener as beholders. Striking visual factors repeatedly emerge as the rhetorician is depicting both himself as an observer $(\dot{\varepsilon} \gamma \dot{\omega} \delta \dot{\varepsilon}$

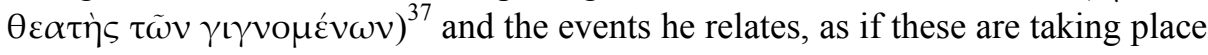
before his very eyes. For example, when commemorating state or court ceremo-

36 Nikephoros Choumnos, Encomium for Andronikos II = Boissonade, Anecdota Graeca (see n. 17), II 52-3.

37 "I too am a spectator at these events": Planoudes, Basilikos (see n. 17), ch. 3, 70. 
nial, orations present vivid descriptions of universal merriment, processions of high dignitaries and common folk, and even glimpses of specific customs and rituals accompanying, say, the celebration of an imperial triumph, ${ }^{38}$ coronation $^{39}$

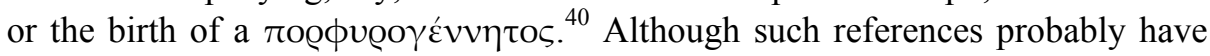
very little to do with the actual performances of the orations, they set the scene for them, and may also prove valuable for the general topic of Byzantine ceremonial.

Not all imperial orations, however, include such features. Quite a few do not convey any elements of ritual, or, for that matter, any trace of performativity. If we read, for example, the orations for Andronikos II by Nikephoros Gregoras ${ }^{41}$ and Theodore Hyrtakenos, ${ }^{42}$ or the two fifteenth-century anonymous compositions for John VIII, ${ }^{43}$ the obvious lack of a strong authorial voice and of display imagery in them suggests that their theatron was envisaged as, and indeed may have been, far less imposing.

\section{The Author/Performer}

Late Byzantine imperial orations were written by highly skilled rhetoricians, who established themselves firmly as the core of the contemporary literary and political elite. A list of titles and offices held by these encomiasts offers only a relative variety. Among them we find future emperors and grand logothetes or mesazones as well as officially appointed orators. Additionally, in their midst we encounter members of the imperial entourage, young court officers and teachers, together with secular clergy, monks and high-ranking church officials, including bishops and patriarchs.

The most prominent intellectuals in late Byzantium frequented the imperial court in Constantinople and performed in literary salons, which were at times presided over by the emperor. These intellectuals were well acquainted with each

38 Holobolos, Oration II, 68-75; George of Cyprus, Encomium for Michael VIII, ff. 347; Kydones, Oration II for John VI, passim.

39 Planoudes, Basilikos, ch. 36, 1186-94.

40 Holobolos, Oration III, (ed. Treu, Holoboli orationes [see n. 15], 78-98, 91, 3-11); Choumnos, Encomium for Andronikos II 13.

41 Nikephoros Gregoras, Oration I for Andronikos II = L. Schopen/J. Bekker (eds.), Byzantina Historia Nicephori Gregorae, Bonn 1829-1855, I, 328, 9-339, 20. Nikephoros Gregoras, Oration II for Andronikos II = P. A. M. Leone, Nicephori Gregorae ad Imperatorem Andronicum II Palaeologum orationes, in: Byz 41 (1971) 503-10. Nikephoros Gregoras, Oration III for Andronikos II = ibidem, 510-15.

42 Theodore Hyrtakenos, Address to Andronikos II = Boissonade, Anecdota Graeca, I, 248-53.

43 Anonymous I, Encomium for John VIII Palaiologos, ed. S. Lampros, П $\alpha \lambda \alpha$ เo

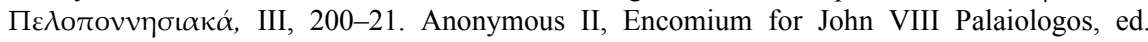
ibidem, 292-308. 
other, and they kept in touch with their colleagues outside Constantinople. Their abundant correspondence allows us to establish a more detailed picture of the intricate social scene of most prominent Palaiologan intellectuals, while evidence of their personal contacts can lead us to identify the influence one such author had on others. ${ }^{44}$

Imperial encomiasts follow the same pattern. A further proof of their mutual association can be found in the fact that most among them were connected by the relationship of student and teacher. We know, for example, that George Akropolites was George/Gregory of Cyprus's teacher while he, in turn, taught Nikephoros Choumnos, and probably Maximos Planoudes, too. It is assumed that Choumnos took part in the education of Manuel Gabalas/Matthew of Ephesos. Theodore Metochites supervised Nikephoros Gregoras's studies, while Gregoras probably acted as George Lampenos's teacher. Finally, Demetrios Kydones was a tutor of another imperial encomiast, Manuel II Palaiologos. These connections become particularly important when we consider the fact that the production of imperial orations in late Byzantium relied heavily on the contemporary rhetorical production, and that Palaiologan rhetoricians appear to have drawn their inspiration primarily from similar compositions that were chronologically and thematically closest to them. ${ }^{45}$

While these data allow us to assume that links between the rhetoricians were strong and, probably, friendly, we must not exclude the possibility that some orators displayed a somewhat less sociable disposition towards their colleagues. The competition, envy and intrigues at the court of Manuel II Palaiologos, as described in the work attributed to Mazaris, even if exaggerated for satirical purposes, could not have been entirely fictional, nor, for that matter, relevant to a single reign only. ${ }^{46}$ Nevertheless, due to their deliberate obscurity, imperial orations are not the most suitable sources to bear witness to polemical, even competitive, sentiments that might have existed between their authors. Cases where they can be recognised are rare. ${ }^{47}$ On the other hand, what we can find in late Byzantine imperial orations are ever-increasing elements of personal opinion and ad-

44 On contacts between intellectuals in late Byzantium, see: K. P. Matschke/F. Tinnefeld, Die Gesellschaft im späten Byzanz: Gruppen, Strukturen und Lebensformen, Cologne 2001, 221 385.

45 I. Toth, Epideictic eloquence in late Byzantium - imperial orations in the light of their rhetorical tradition and contemporary practice (abstract), published in: Proceedings of the 21st International Congress of Byzantine Studies. II Abstracts of Panel Papers, London 2006, 135.

46 Mazaris' Journey to Hades, Greek text with translation, notes, introduction and index by Seminar Classics 609, Buffalo, N.Y. 1975, 2-60.

47 A convincing suggestion has been made recently to identify the anonymous opponent of Planoudes, whom he mentions in his Basilikos, as Nikephoros Choumnos: Angelov, Byzantine Imperial Panegyric (see n. 8), 62-3. 
vice. If at any point in their history Byzantine intellectuals felt obliged to take a stance and voice their concerns, this was certainly their time. Parainesis and assessment - sporadic in earlier epideictic compositions - became the most prominent features of speeches dedicated to the Palaiologan basileus. Whether their authors intended to suggest possible political action, or to comment upon steps already taken, they were far more explicit than the nature of their work demanded. Understandably so, for, these rhetoricians were frequently the executors of imperial policies and, more often than not, their creators. However, we must not ignore the fact that even deteriorating Byzantine circumstances and the irreversibly altered character of imperial orations in these circumstances, did not make Byzantine orators lose sight of the encomiastic tradition and the true character of the task they performed, which they maintained until the very last days of the dying empire.

The rhetorician's art is the art of self-presentation and the epideictic genos generally serves as a most efficient vehicle for this aim. In this context, what often emerges is the portrait of a speaker promoting the ideas of display and giving a self-validating performance in equal measure. In the Palaiologan imperial encomia the performer takes the centre stage. He chooses first-person narration as the form of his presentation, and also includes numerous self-referential elements. It is in the name of the entire population that he acts as $\eta \pi \alpha \dot{\gamma} \delta \eta \mu \mathrm{s} \kappa \alpha \dot{\mathrm{i}}$ $\pi \alpha \gamma \kappa$ có $\mu$ tos $\phi \omega v \eta$, for one voice, one mouth and one tongue do not suffice

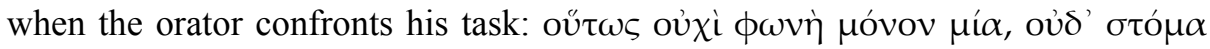

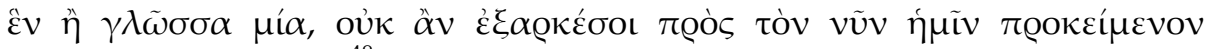

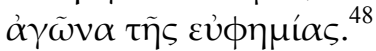

Imperial encomiasts, as we have seen, consider themselves truthful representatives of the entire Byzantine populace. Their task of praising the emperor is embedded in a deeper context of reinforcing generally accepted values. Generalisation and didacticism are integral to their presentation. Responding to such expectations, the encomiasts are very close to being educators. Moreover, concerning themselves with the process of influencing audiences, and exerting power over them, they alternate between the roles of orators - far better suited to the task they perform - and of actors. ${ }^{49}$ Even though they mostly speak in their own name and assume ethical responsibility for their own words, at times they lend their

48 Choumnos, Encomium for Andronikos II, 1, 12 - 2, 22.

49 On theatrical representation and two men of spectacle (orator versus actor), see: J. Derrida, Of Grammatology, Baltimore 1997, 305: "There are two sorts of public persons, two men of spectacle: on the one hand the orator or the preacher, on the other the actor. The former represents himself, in him the representer and the represented are one. But the actor is born out of the rift between the representer and the represented ... He signifies nothing. He hardly lives, he lends his voice. It is a mouthpiece ..." 
voice and act as mouthpieces, reporting, verbatim, words they explicitly attribute to others. ${ }^{50}$

\section{The Audience}

A complete decoding of the Byzantine imperial oration proves almost as challenging for the reader today as it must once have been for the great majority of Byzantine public. Addressed to the emperor and composed by and for the literary elite, the Byzantine imperial oration was never intended for a wider audience and readership. Instead, its intricate and fine-tuned details could be grasped only by those individuals equipped with sufficient insight and background information to follow what was being communicated. The audience members for the Byzantine imperial oration were defined by their high learning, esoteric knowledge, dominant position in Byzantine society and, ultimately, by the proximity to the person praised - the Byzantine emperor himself. In the Palaiologan imperial orations, the emperor and the audience are always in attendance, and play an important role in the performance. And yet, in spite of their strong presence, they remain elusive.

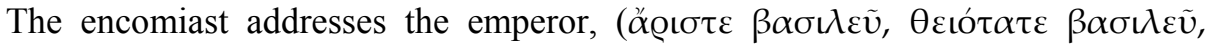
$\theta \varepsilon \tilde{\varepsilon} \varepsilon \dot{\eta} \gamma \varepsilon \mu \omega \dot{v}$, etc.), and at times other members of the imperial family, often leaving no doubts that his act is graced by their presence. Frequently, it is made clear that the heir to the throne or the empress attend such occasions. ${ }^{51}$ Then there

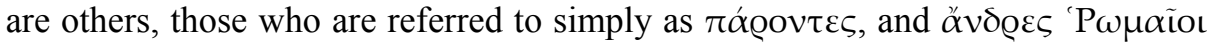

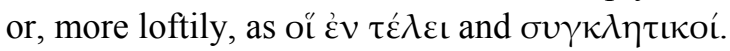

Only in one unrepeated case are we told explicitly who graced the performance of an imperial oration. Here I refer to the last surviving chapter of Akropolites's historical work, where the author mentions that the emperor and high dignitaries were present at the performance of his own speech. ${ }^{52}$ Among these

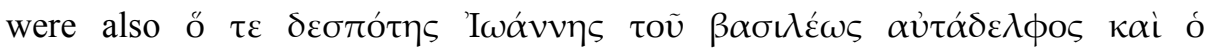

50 Holobolos, in his Oration I, 45, 32-46, 1, 36 reports the speech the Genovese envoys delivered for the emperor; in the first anonymous oration for John VIII $(216,31-218,33)$, the unknown rhetorician quotes the emperor's address to his subjects, in which he urges them to preserve their Christian faith. On the other hand, George/Gregory of Cyprus, in his Encomium for Michael VIII $(348,24-351,22)$ composes a prosopoiia, and reports a speech, which the city of Constantinople pronounces paying respect to her liberator, the emperor.

51 The empress Anne of Savoy seems to have attended the oration by the Patriarch John XIV

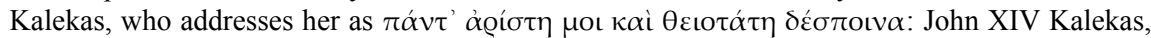
Coronation Speech, 43, 1-2. Both Planoudes in his Basilikos and Chortasmenos in his Prosphonetikos frequently address Andronikos II and his son Michael IX and Manuel II and his son John VIII respectively.

52 Heisenberg, Acropolitae Opera (see n. 22), I 188.19-189.8. 


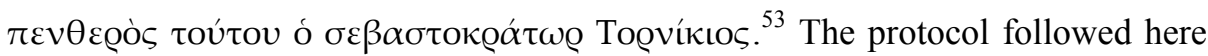
must have been the same as for any other ceremonial gathering at the palace. The audience most probably consisted of senators, officials and other patricians (oi

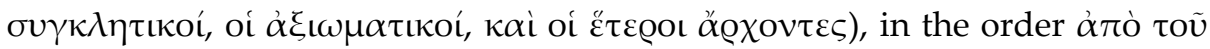

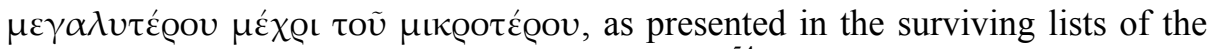
hierarchy at the imperial court in late Byzantium. ${ }^{54}$ For all this effort, Akropolites witnessed how such a worthy assembly was not entirely appreciative of his intentions. As he describes, the emperor was displeased, and it was noon and time for

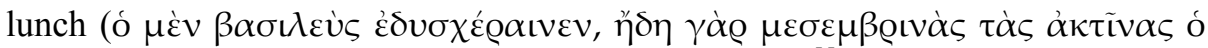

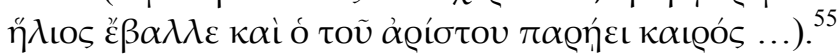

The attendance at such gatherings remains a highly speculative topic, and one, which has yet to be investigated more thoroughly. One detail, however, remains undisputed: the higher the social standing of the public, the better placed it was to mark the occasion and to confirm the authority of the performer.

There is another aspect of imperial orations, which may offer a wealth of information on the presentation of these occasional rhetorical pieces. Here I refer the active communication between the orator and his public described in the orations themselves. Almost always the orator invites the public to participate actively in his performance. Quite common in the declamatory rhetoric of this type is the use of the plural voice, of exhortations, imperatives, questions, exclamations, commands, and expressions of wishes. Through these forms, the speaker urges the audience to listen to him, to join in, to eulogize (or curse), applaud or to pray, as is appropriate when great celebrations take place. These тó $\pi 0$ are frequent and seem to suggest that there was some kind of communication among the participants in the performance. Of course, such references may simply be poetic devices, rather than reflecting an actual practice. We cannot be certain, but it would be careless, to say the least, to dismiss such an abundance and such consistency of information. Moreover, current research on the performance of Byzantine poetry, and of panegyrical poems in particular - the compositions whose purpose and original context must have been very similar to those of prose panegyrics - indicates that there is much to be gained from focusing on these issues. ${ }^{56}$

53 Ibidem, 188.30-189.1.

54 J. Verpeaux (ed.), Traité des offices (Le monde byzantin 1), Paris 1966, 130-40; 344-9.

55 Heisenberg, Acropolitae Opera (see n. 22), I 189.6-8.

56 Classical scholars have already done a great deal of work on this topic. See, for example: G. Nagy, Poetry as performance: Homer and beyond, New York 1996. On the performance of Byzantine court poetry, see: M. Alexiou, Ploys of Performance: games and play in the Ptochoprodromic poems, in: DOP 53 (1999) 91-109; W. Hörandner, Zur kommunikativen Funktion byzantinischer Gedichte, in: XVIII International Congress of Byzantine Studies, Major Papers, Moscow 1991, 104-18; M. Jeffreys, "Rhetorical" texts, in: E. Jeffreys (ed.), Rhetoric in Byzantium, Papers from the Thirty-fifth Spring Symposium, Exeter-College, University of Oxford, 
I suggest that exactly this approach offers a way forward in reading and interpreting the performance of rhetorical texts in general. A careful examination of self-referential elements, of dramatic rendering and deictic language could successfully replace the missing testimonies of performance. Evidence that such data provide is both plentiful and valuable and cannot be ignored.

\section{The Sign of a Sign - written versus oral}

From the point of view of their utility, late Byzantine imperial orations display a dual nature. On the one hand, these texts were undoubtedly composed in order to be performed; on the other, they were also written in order to be read. Although pieces of occasional rhetoric, not all imperial orations were intended to be merely short-lived compositions with a significance as ephemeral as the public events to which they were attached. In order to corroborate this, one final remark is due concerning the role of imperial encomiasts as publishers and distributors of their own works. Only rarely are we allowed an insight into this aspect of their work, but when this happens, it becomes clear that some speeches were drafted in more than one version, and were distributed inviting advice and evaluation. At times, they were also subject to a gradual editorial process, even in the aftermath of the events, which inspired them.

I offer several cases in point. The aforementioned Michael Gabras refers in one of his letters to an oration he wrote for Andronikos II, stating that he has forwarded this text to all his learned friends. The letter itself is headed toĩ

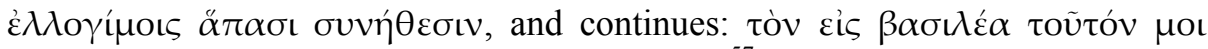

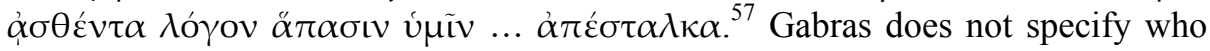
his friends were, nor what the purpose of the circular was, but we can assume that by taking charge of the distribution of his own oration, he hoped to ultimately reach the emperor. Another example of the circulation of rhetorical works is provided by Manuel II Palaiologos, who composed a funeral oration for his brother Theodore in $1407 .{ }^{58}$ This text, subject to several revisions, was read and commented upon by some of the emperor's closest friends, and even despatched to Italy in order to be translated into Latin. ${ }^{59}$ Isidore of Kiev gives further evidence of redrafting in the case of his encomium for John VIII. The surviving manuscript tradition of this work attests to different stages in its composition before the final

March 2001, Aldershot 2003, 87-100; M. D. Lauxtermann, Byzantine Poetry from Pisides to Geometres (WBS XXIV/1), Vienna 2003, 45-53.

57 Fatouros, Briefe des Michael Gabras (see n. 32), no 286.

58 Ed. J. Chrysostomides, Manuel II Palaeologus: Funeral Oration on His Brother Theodore (CFHB XXVI - Series Thessalonicensis), Thessalonica 1985.

59 Ibidem, 29-31. 
version. ${ }^{60}$ Although it is not clear whether the encomium was being corrected prior to or after its delivery, the fact remains that it was meticulously edited with a view to improving the text.

We are fortunate that the production of late Byzantine imperial orations is testified to by contemporary, and therefore reliable, material. Here, I refer to the fact that most manuscripts containing late Byzantine imperial orations were copied at the same time as the orations were actually composed. ${ }^{61}$ Furthermore, a great majority of the imperial orations dating from the fourteenth century and thereafter have survived in the collected works of individual authors and, in same cases, they are also autographs. ${ }^{62}$ In fact, this seems to have been by far the most common means of their transmission. It thus becomes possible to identify specific criteria that lead to the addition of imperial orations to such manuscripts, and, since some of them are autographs, to trace these criteria back to the author himself.

It is a well-known fact that Byzantine intellectuals employed rhetoric in their quest for recognition, as well as to further their individual or collective interests. Consequently, their success depended on achieving an opportunity to present themselves to the emperor, and then on the impression they made on him. Our knowledge does not allow us to claim that all extant late Byzantine imperial orations served this purpose, but we do know that many, in fact the great majority of them, were delivered in public. It does not therefore seem unreasonable to propose that the successful performance of these compositions may have influenced the subsequent interventions of their authors, who made sure that their work out-

60 G. Mercati, Scritti d'Isidoro, il cardinale Ruteno, e codici a lui appartenuti, Rome 1926, 6; O. J. Schmitt, Kaiserrede und Zeitgeschichte im späten Byzanz: ein Panegyrikos Isidors von Kiew aus dem Jahre 1429, in: JÖB 48 (1998) 214 and note 25.

61 This is the case with the manuscripts of encomia by Manuel/Maximos Holobolos, Manuel/Maximos Planoudes, Nikephoros Choumnos, Theodore Metochites, Nicholaos Lampenos, Theodore Hyrtakenos, Manuel Gabalas/Matthew of Ephesos, Nikephoros Gregoras, John Kalekas, Manuel II Palaiologos, John Chortasmenos and Isidore of Kiev. The same appears to have been the case with the three known anonymous imperial orations dating from the Palaiologan period.

62 They are: Leid. B. P. G. 49, Paris. Gr. 3010 (George/Gregory of Cyprus), Paris. Gr. 2105 (Nikephoros Choumnos), Vind. Phil. Gr. 95 (Theodore Metochites), Paris. Gr. 1209 (Theodore Hyrtakenos), Vind. Theol. Gr. 174 (Manuel Gabalas/Matthew of Ephesos), Vat. Gr. 116, 1085, 1086 (Nikephoros Gregoras), Laur. LIX 44 and Burney. Gr. 75 (Demetrios Kydones), Paris. Gr. 1213 (Nicholas Kabasilas), Paris. Coisl. Gr. 286 (John Kalekas), Paris. Gr. 3041 (Manuel II Palaiologos), Vind. Suppl. Gr. 75 (John Chortasmenos), Vat. Gr. 226 (Isidore of Kiev), Saragoss. 84 (John Dokeianos), Vind. Phil. Gr. 85 and Monac. 51 (Michael Apostoles). Among the manuscripts numbered above the autographs are: Vind. Theol. Gr. 174 (Matthew of Ephesos), Vat. Gr. 116, 1085, 1086 (Gregoras), Paris. Gr. 3041 (examined and annotated by Manuel II), Vind. Suppl. Gr. 75 (Chortasmenos), Vat. Gr. 226 (Isidore of Kiev). 
lived its original function and was left for posterity as a memento of their own achievements.

It was this particular aspect of their activity that made the rhetoricians' "exchange" with the emperor even more beneficial to both parties: "High culture poetry, rhetoric, history, on occasion philosophy is the panegyrist's main contribution to the glory of the emperor. It sets him in a heroic and historical context. It offers a memorial which, in virtue of its archaic and supposedly timeless language, promises immortality." ${ }^{, 63}$ Neither Byzantine imperial encomiasts nor their

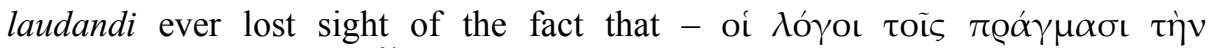

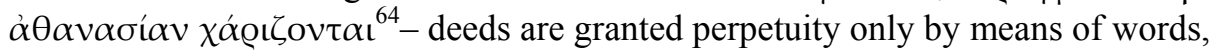
be they spoken or written. On this premise alone, the authors of the orations dedicated to the emperor could confidently claim their recompense, even if it meant releasing their compositions, and allowing their Nachleben to evolve into a different type of performance, for a different audience - their reading public.

63 D. A. Russell, The Panegyrists and their Teachers, in: M. Whitby (ed.), The Propaganda of Power: the role of panegyric in late antiquity (Mnemosyne suppl. 183), Leiden 1998, 43.

64 Isidore of Kiev, Encomium for John VIII, ed. Lampros, П $\alpha \lambda \alpha$ เo III $133,21-2$. 